\title{
Human resource management trends in Slovakia
}

\author{
Katarina Stachova \\ Institute of Civil Society, University of $S_{s .}$. Cyril and Methodius, \\ Slovakia \\ katarina.stachova@ucm.sk \\ ORCID 0000-0003-4761-2509 \\ Zdenko Stacho \\ Institute of Civil Society, University of Ss. Cyril and Methodius, \\ Slovakia \\ zdenko.stacho@,ucm.sk \\ ORCID 0000-0001-5588-8340
}

\author{
Agota Giedrè Raišienè \\ Institute of Leadership and Strategic Management, Mykolas Romeris University, \\ Lithuania \\ agotar@mruni.eu \\ ORCID 0000-0002-4641-7616
}

\author{
Alexandra Barokova \\ Faculty of Management, Comenius University, \\ Slovakia \\ alexandra.barokova@fm.uniba.sk
}

Abstract. Human potential introduces an enormous range of knowledge, skills, predictable and unpredictable responses, ways of perception, experience, and behaviour. The human potential in the corporate environment, i.e. people and their complex positive and negative abilities are mostly constructive, but sometimes destructive creators of new values and new knowledge. The need to implement changes in management systems is a challenge and a condition for future competitiveness these days. In this paper, the authors focus on the culturalhistorical development of human resource management from the time when people were only a secondary component of production to the present when they are a key element in maintaining competitiveness. A survey conducted between 2010 and 2019 analyses how human resource management in Slovak organizations has changed over the past decade. The survey revealed several

Received: January, 2020 1st Revision: May, 2020

Accepted: September, 2020

$10.14254 / 2$ $8330.2020 / 13-3 / 21$ 
findings. The most fundamental is the trend of increasing the size of human resource management units or personnel departments in organizations.

Keywords: human resource management, historical-cultural context of change, human potential management, current management trends, Slovakia.

JEL Classification: O15, J24

\section{INTRODUCTION}

The role of a person in an organization has changed significantly over time. At the beginning, employees were considered only as a supplement to the machine which they had to perform work with. Currently, organizations are realizing that it is the employees and their potential, perceived in organizations as human capital, that is the decisive variable for its performance, competitiveness, and future. This is gaining importance with the oncoming of the Fourth Industrial Revolution, as competitive technology or its financial strategy can be imitated much easier than imitating the soft aspects of management and development within an organization. Human potential can be perceived as the only and unique, living and reviving, dynamic and dynamizing power of an enterprise (Cagáňová et al. 2019; Stacho et al. 2019; Stacho et al., 2017; Vojtech et al. 2019; Papula et al. 2018; Hitka et al. 2017). Identifying, exploiting, motivating, and developing constructive human potential involves meaningful and systematic effort that is nowadays perceived as the management and development of human potential (Blašková, 2003). It is this management, the development and support of employees in the organizations that is covered by the Human Resource Department or the Personnel Department of an organization. Current practice shows that these departments should become a sort of business partners within the organization and whose clients should be the most valuable thing an organization has - its employees, the human capital. These changes in the perception of a person - employee have changed very gradually and fundamentally over a period of more than 100 years, which is outlined in the following sections.

Knowledge of the current state of human resource management and its alignment with modern tendencies in the given area can be described as a basic prerequisite for an organization's improvement and gradual approach to the level of advanced organizations in the world (Steffensen et al., 2019; Kampf et al. 2017; Stacho \& Stachova 2015; Jenco et al. 2018).

In the context of recession and economic crisis, which culminated in the European Union in the period just after 2010 and the onset of the Fourth Industrial Revolution, the authors examine the trends in human resource management based on the example of Slovak organizations between the years 2010 and 2019. With this purpose, a broadly designed survey in randomly selected companies was conducted.

\section{HIGHLIGHTS OF HUMAN RESOURCE MANAGEMENT IN THE HISTORICAL CONTEXT}

Human resource management, formerly personnel management, or personnel administration have their roots at the end of the 19th and beginning of the 20th century. Until then we can only speak of hardworking men and often women and children in bad conditions and for minimum wages (Reidy, 2015). Although in 1838 the French industrialist D. Legran approached governments of European countries with the offer to approve international laws on working conditions. In the second half of the 18th century, Owen called his workers "living machines" and pointed out the need for as "inanimate machines" (Gorb, 1951). It was not until 1890 that representatives of 14 European countries made recommendations in Berlin as a 
guidance for states to implement and endorse labor law standards (Vojtovoč 2006). The roots of human resource management can be found around this time.

The period between 1890 and 1920 can be characterized by an increase in the importance of man at work. All employees were required to have certain expertise, and the personality characteristics of the worker were also considered. Since in this period human still adapts to the utilization of the machine, an individual was perceived as a secondary component of production (Vojtovič, 2006). Though this period can be called as "Care for Employees." (Armstrong, 1999), unfortunately, the level of care provided, as well as other primitive methods of psychological influencing of workers, had not produced the expected results (Skott et al., 1941).

The next period of organizations' focuses on employees and their needs and can be called as a "personnel administration phase" (Armstrong 1999). In this period, the HR departments provided management, in addition to employee care, with assistance in the form of recruitment, training, and recordkeeping of workers. Many companies set up departments aimed at maintaining the well-being of workers. The model of social care in this period were companies of Tomáš Bata, who provided his employees with above-average wages, systematic and effective education, flats and houses for employees, health care and insurance (Mach, 1932). On the one hand, this period of the 1930s was characterized by an increase in the performance of the American and European economies, but also by the onset of the first economic crisis, accompanied by high unemployment on the other hand, and a significant increase in state regulation.

The period of 1930-1950 is referred to as the Personnel Development Phase (Armstrong, 1999). During this period, Mayo and Roethlisberger found out that workers were more responsive to social factors, such as the level of attention of their managers and the feeling that their managers were really interested in their work and them, as in the quality of the environment. Increasing worker satisfaction with work was mentioned as a means of increasing their productivity (Chukwunonso, 2013). This period was also a period of alleviation of conflicts between employees, and administrative, and management staff in organizations. An ordinary employee was no longer understood as a "part of the production line or machine accessory," but as a human being. Although significant progress was made in the field of personnel management in Europe, it remained focused on the in-house problems of employing people and managing their work skills (Koubek, 2007). On the other hand, at this time, union membership grew significantly in the United States between 1935 and 1950, which led to a greater emphasis on collective bargaining and employee relations in personnel management. Compensation and benefit management were also important as trade unions negotiated paid holidays and insurance coverage (Chukwunonso, 2013).

The period between 1950 and 1970 is referred to as the period of the Personnel Development (Maturity). Trends in post-war economic development changed the sectoral and professional structure of employees. The proportion of unskilled workers was reduced to a minimum, and the proportion of highly qualified workers, engineers, technicians, managers and other professionals with higher education was increased. In the 1960s, Shein came with the cognition that a man is complex, and the manager must be able to estimate the motive that the man is currently following (Vojtovic, 2006). For this reason, the personnel management services significantly expanded in this period. These include the systematic training and development of employees according to the individual needs of the employee, the use of more sophisticated techniques for the selection, compensation, and evaluation of employees. Emphasis was placed on the social climate, employment legislation, such as safety conditions at work, health conditions, pensions, and even discrimination in the workplace is changing significantly towards employees. The introduction of the process of planning and developing the career of employees was considered to be a management discovery from the late 1970s in improving the concept of personnel management.

The concept of human resource management began to develop during 1970 - 1990 period. Based on this concept, a close link between the organization's strategy and a system in which individual activities were 
coordinated and integrated to work together to improve organizational performance was highlighted (Kepes \& Delery, 2007). While in the conditions of industrial production the personnel management object was the personal and employment relationships of workers as a source of labor force, in the new economic conditions the management object was the worker, which was the main production source, production capital and capital of the organization. This concept sometimes was considered as overly optimistic and based on promises and expectations rather than on arguments (e.g. Guest, 1991; Blyton \& Turnbull, 1992; Mabey et al. 1998). The main objections to the concept of human resource management stemmed from the view of people, and opponents of the concept pointed out that people cannot be considered as resources of traditional understanding, such as material, financial or information resources (Bajzíková \& Kirchmayer, 2019).

In the last decade of the 20th century, the concept of strategic human resource management has gradually come into the language of both theoreticians and professionals. Under the strategic management of an organization, they understand the process in which top management sets the goals of the organization and ways of achieving them. This process was carried out by developing the organization's vision and mission, setting strategic goals, formulating strategies, evaluating results and adopting the necessary corrections. The strategic human resource management included activities related to the design and implementation of internally consistent human resource policies and practices, their individual and collective knowledge, skills and capabilities, and their optimal use to contribute to the goals of the organization as a whole. The management of human resources acquires a strategic character depending on the extent to which personnel strategies contribute to organizational efficiency and to what extent they succeed (Ericksen \& Dyer, 2005). Knowledge and skills in strategic planning, project management, process analysis and change management were necessary in making top-level strategic decisions, but also to ensure that these were successfully implemented in working life and understood by employees as a part of their job (Green, 2002). Being the powerful background of the organisational development, knowledge management and knowledge transfer still play a crucial role in human resources management (Poór et al., 2018) and consequently, have an obvious positive impact on long-term organizational and business success (Tabatabaei et al., 2017).

Finally, current time human resource management systems participate in the conception and implementation of business strategies in conditions of developed globalization with a high degree of interconnectedness. This is dominated by the potential of competition from all over the world, where the basic conditions are increasing demands for innovation capacity and short time to market. Within the concept of strategic human resource management, there is a requirement to transform departments of human resource management into so-called human resource management business partners. The HR departments become a full-fledged partner of their internal client, bringing businesses a clear added value. A strategic business partner becomes a specialist for managing people, who can effectively manage the processes that add value to the internal customer team (for example talent or career management). It is valued for its experience and direct connection with an internal customer. The most important trend of the last decades, and we would like to say that even the next decades, has been and will be the digitalization of the world of labor, which is an essential accompanying feature of the fourth industrial revolution. The digitization processes are followed by many current trends in the field of human resource management and development (Sorko, 2016; Makarova et al., 2018; Zhou et al., 2020), including the development of ICT skills by employees regarding to organisational goals achievement (Bilan et al., 2019). Digital transformation affected career management, training and development, performance management as well as intensified processes in building a knowledge-based society, employee mobility, and networking (Baykal, 2020; Blštakova et al., 2020; Raišienė et al., 2020; Rapuano, 2020). 


\section{METHODOLOGY}

Based on the set objectives, a survey was conducted each year in randomly selected enterprises, based on a broadly conceived questionnaire containing 95 questions. The questions had the form of open, closed and scale answers.

The surveys were conducted between the years 2013 and 2019, always between February and May. The survey respondents were top representatives of Slovak companies. The questionnaire was delivered personally. The number of managers addressed annually oscillated around 570, with a backflow of complex and correctly completed questionnaires ranging from $60 \%$ to $65 \%$.

The research sample consisted of managers operating in companies throughout Slovakia. The authors set two stratification criteria to determine a sufficient research sample. The first criterion was the region of operation of the enterprise under the NUTS system, specifically Slovakia divided according to the NUTS 2 category. The samples were based on data from the Statistical Office of the Slovak Republic.

As a second stratification criterion was that the minimum number of employees in the surveyed enterprise is 50, thus excluding micro and small enterprises from the research sample On the other hand, this criterion selected companies in which due to the number of employees, the skills of managers will be realistically reflected

Based on data from the Statistical Office of the Slovak Republic during the period under review, the number of enterprises with 50 or more employees in individual regions oscillated around the same values, the specific regional structure of enterprises with more than 50 employees in the surveyed years is shown in Table 1 below.

Table 1

Regional structure of enterprises with over 50 employees

\begin{tabular}{|l|c|c|c|c|}
\hline Region - NUTS II. & $\begin{array}{c}\text { Bratislava } \\
\text { region }\end{array}$ & Western Slovakia & $\begin{array}{c}\text { Central } \\
\text { Slovakia }\end{array}$ & Eastern Slovakia \\
\hline Region & BA & TT, TN, NR & BB, ZA & KE, PO \\
\hline Number of enterprises 2010 & 1,096 & 902 & 645 & 613 \\
\hline Number of enterprises 2011 & 1,084 & 897 & 641 & 609 \\
\hline Number of enterprises 2012 & 1,067 & 890 & 638 & 604 \\
\hline Number of enterprises 2013 & 1,074 & 895 & 639 & 603 \\
\hline Number of enterprises 2014 & 1,098 & 904 & 644 & 612 \\
\hline Number of enterprises 2015 & 1,105 & 916 & 651 & 613 \\
\hline Number of enterprises 2016 & 1,114 & 923 & 649 & 621 \\
\hline Number of enterprises 2017 & 1,123 & 926 & 654 & 623 \\
\hline Number of enterprises 2018 & 1,125 & 930 & 659 & 627 \\
\hline Number of enterprises 2019 & 1,137 & 935 & 661 & 626 \\
\hline
\end{tabular}

Source: Statistical Office of the Slovak Republic; Authors' calculations.

The authors determined the optimal research sample from the above-mentioned sample of enterprises with a 95\% confidence level of research and a confidence interval of results $(\mathrm{H}=+/-0.10)$. Based on the above criteria, a sufficient and relevant research sample was determined for individual regions of Slovakia in the analyzed years, which is shown in Table 2 . 
Determination of research sample for respective regions of Slovakia

\begin{tabular}{|l|c|c|c|c|}
\hline Region - NUTS II. & $\begin{array}{c}\text { Bratislava } \\
\text { region }\end{array}$ & $\begin{array}{c}\text { Western } \\
\text { Slovakia }\end{array}$ & $\begin{array}{c}\text { Central } \\
\text { Slovakia }\end{array}$ & $\begin{array}{c}\text { Eastern } \\
\text { Slovakia }\end{array}$ \\
\hline Region & BA & TT, TN, NR & BB, ZA & KE, PO \\
\hline Size of the sample & 88 & 87 & 84 & 83 \\
\hline
\end{tabular}

Source: Authors’ calculations.

\section{EMPIRICAL RESULTS AND DISCUSSION}

\subsection{Banks ownership and relationship lending}

The authors consider the existence of the human resource management department or the personnel department as an important feature of the organization with a direct connection to the main objective of the survey.

Table 3

Existence of human resource management department or personnel department

\begin{tabular}{|c|c|c|c|c|c|c|c|c|c|c|}
\hline $\begin{array}{c}\text { Existence of HRM or } \\
\text { Personnel department }\end{array}$ & $\mathbf{2 0 1 0}$ & $\mathbf{2 0 1 1}$ & $\mathbf{2 0 1 2}$ & $\mathbf{2 0 1 3}$ & $\mathbf{2 0 1 4}$ & $\mathbf{2 0 1 5}$ & $\mathbf{2 0 1 6}$ & $\mathbf{2 0 1 7}$ & $\mathbf{2 0 1 8}$ & $\mathbf{2 0 1 9}$ \\
\hline Ratio of organizations in \% & 66.2 & 70.1 & 67.4 & 74.7 & 76.3 & 81.6 & 75.6 & 79.5 & 85.3 & 85.4 \\
\hline
\end{tabular}

Source: Author's calculations.

In the analyzed years, 66 to $85.4 \%$ of organizations declared the existence of human resource management department or personnel department, or at least the HR manager. The upward trend in the existence of these departments was almost continuous throughout the period under review (Table 3). The authors consider this trend very positive, but they still perceive room for improvement.

After that, the authors also focused on other facts affecting the management of human resource in the organization. They investigated where the person, currently responsible for human resource management issues, was recruited from. The aim of this question was to find out if organizations prefer to recruit employees for such a strategic position from internal or external sources and whether their practical experience in the field is emphasized.

Table 4

Source from which the person, currently responsible for HRM issues, was recruited

\begin{tabular}{|c|c|c|c|c|c|c|c|c|c|c|}
\hline \multirow{2}{*}{$\begin{array}{c}\text { Person responsible for HRM } \\
\text { was recruited from: }\end{array}$} & \multicolumn{10}{|c|}{ Ratio of organizations in $\%$} \\
\hline & 2010 & 2011 & 2012 & 2013 & 2014 & 2015 & 2016 & 2017 & 2018 & 2019 \\
\hline \multicolumn{11}{|l|}{ One of the internal sources: } \\
\hline From the HR department & 23.4 & 28.3 & 24.1 & 30.2 & 27.6 & 29.5 & 28.9 & 30.8 & 28.8 & 29.9 \\
\hline $\begin{array}{l}\text { Among employees, but not HR } \\
\text { department }\end{array}$ & 27.6 & 30.1 & 26.4 & 24.2 & 26.4 & 23.9 & 22.2 & 19.9 & 21.2 & 21.3 \\
\hline \multicolumn{11}{|l|}{ One of the external sources: } \\
\hline $\begin{array}{l}\text { Worked in HR department in } \\
\text { different company }\end{array}$ & 34.5 & 20.2 & 24.3 & 29.9 & 32.4 & 30.8 & 33.7 & 34.4 & 35.3 & 34.1 \\
\hline $\begin{array}{l}\text { Did not work in HR and was } \\
\text { not an internal employee }\end{array}$ & 16.7 & 22.1 & 26.8 & 15.7 & 14.5 & 15.8 & 15.2 & 14.9 & 14.8 & 14.7 \\
\hline
\end{tabular}

Source: Author's calculations. 
The survey showed that organizations use external and internal resources almost equally to fill the human resource department, and in both cases, staff with practical experience in HR management prevails, with the difference being more significant for external resources (Table 4).

The authors also focused on finding out whether the person responsible for human resource management has a place in top management or in another top executive team of the organization.

Table 5

Existence of a position in the organization's management for the person responsible for HRM

\begin{tabular}{|c|c|c|c|c|c|c|c|c|c|c|}
\hline $\begin{array}{c}\text { Existence of a position in the } \\
\text { organization's management for } \\
\text { the person responsible for } \\
\text { HRM }\end{array}$ & $\mathbf{2 0 1 0}$ & $\mathbf{2 0 1 1}$ & $\mathbf{2 0 1 2}$ & $\mathbf{2 0 1 3}$ & $\mathbf{2 0 1 4}$ & $\mathbf{2 0 1 5}$ & $\mathbf{2 0 1 6}$ & $\mathbf{2 0 1 7}$ & $\mathbf{2 0 1 8}$ & $\mathbf{2 0 1 9}$ \\
\hline \begin{tabular}{c} 
Ratio of organizations in \% \\
\hline
\end{tabular} & 23.5 & 40.4 & 49.2 & 52.8 & 54.7 & 56.2 & 55.0 & 55.8 & 54.9 & 55.1 \\
\hline
\end{tabular}

Source: Author's calculations.

The survey showed (Table 5) that over half of Slovak companies have a person in charge of human resource management in top management, and this level was reached in the fourth year of analysis and remained there until the last year. In the current period, it can be stated that this ratio has stabilized at around $55 \%$.

\subsection{Existence of essential documents}

The creation and form of individual organizational documents are in general entirely at the discretion of the management of the organization. In the context of the awareness or lack of awareness of the need for organizations to create individual organizational documents, the authors investigated the existence or absence of documents defining personnel and diversity strategies.

Table 6

Areas where the analyzed organizations have documents created

\begin{tabular}{|l|l|l|l|l|l|l|l|l|l|l|}
\hline $\begin{array}{c}\text { Does the organization have the } \\
\text { following documents }\end{array}$ & \multicolumn{7}{|c|}{ Yes, the document is in writing in (\%) } \\
\hline & 2010 & 2011 & 2012 & 2013 & 2014 & 2015 & 2016 & 2017 & 2018 & 2019 \\
\hline Personnel Strategy & 54.0 & 53.4 & 51.3 & 49.7 & 48.8 & 46.9 & 42.1 & 50.6 & 52.3 & 53.2 \\
\hline Diversity Code & 15.9 & 17.9 & 18.0 & 19.7 & 21.3 & 25.2 & 25.3 & 29.9 & 26.9 & 28.7 \\
\hline
\end{tabular}

Source: Author's calculations.

The survey showed that only about half of the respondents involved had a strategic concept of human resource management in the form of a normative document. Less than one-third of respondents declared formal diversity of the workforce by defining a diversity code (Table 6).

\subsection{Ensuring selected human resource management functions}

The decision to outsource certain human resource management functions has two main reasons. One is the absence of a professional workforce on the subject and the other is the reason for the organization's transition to the most cost-effective model of its funding. In many cases, it is more convenient for them to delegate some of the selected HR functions to external organizations. 
As a part of the analysis of the current state of providing human resource management functions by organizations, authors were interested in how many organizations and which functions are largely outsourced. The survey showed that the ratio of human resource management functions provided by selfdirected organizations significantly decreased over the period under review (Table 7).

Provision of selected human resource management functions

\begin{tabular}{|c|c|c|c|c|c|c|c|c|c|c|}
\hline & \multicolumn{8}{|c|}{ The degree to which are HRM functions outsourced (\%) } \\
\cline { 2 - 12 } & 2010 & 2011 & 2012 & 2013 & 2014 & 2015 & 2016 & 2017 & 2018 & 2019 \\
\hline Recruitment and selection & 21.3 & 8.5 & 5 & 10.4 & 22.6 & 34.4 & 45.7 & 55.3 & 56.3 & 58.6 \\
\hline Education and development & 35.1 & 28 & 25.9 & 36 & 48 & 71.7 & 69.4 & 69.5 & 71,5 & 72.3 \\
\hline Compensation and benefits & 7.4 & 13.3 & 11.8 & 9.4 & 12 & 15 & 18.5 & 24 & 25.1 & 25.7 \\
\hline $\begin{array}{c}\text { Information service for } \\
\text { management and employees }\end{array}$ & 19.4 & 11.7 & 8.3 & 14.2 & 26.3 & 37 & 46.8 & 55.6 & 53.6 & 55.2 \\
\hline Outplacement and redundancy & 7 & 2.5 & 3.4 & 9.5 & 12.7 & 13 & 14.9 & 22.5 & 21.8 & 24.2 \\
\hline
\end{tabular}

Source: Author's calculations.

Organizations use outsourcing mainly in employee education and development, where the survey shows that already three-quarters of respondents are using this form of support. The majority of respondents also use outsourcing in the area of recruitment and selection of employees and information services.

Table 8

Base change index - a rate of HRM provisioning through outsourcing

\begin{tabular}{|c|c|c|c|c|c|c|c|c|c|c|}
\hline \multicolumn{8}{|c|}{ Base change index - a rate of HRM provisioning through outsourcing } \\
\hline & bi11/10 & bi12/10 & bi13/10 & bi14/10 & bi15/10 & bi16/10 & bi17/10 & bi18/10 & bi19/10 \\
\hline Recruitment and selection & 0.399 & 0.235 & 0.488 & 1.061 & 1.615 & 2.146 & 2.596 & 2.643 & 2.751 \\
\hline Education and development & 0.798 & 0.712 & 1.026 & 1.367 & 2.042 & 1.977 & 1.980 & 2.037 & 2.060 \\
\hline $\begin{array}{c}\text { Compensation and benefits } \\
\text { Information service for } \\
\text { management and employees }\end{array}$ & 1.798 & 1.595 & 1.270 & 1.621 & 2.027 & 2.432 & 3.243 & 3.391 & 3.473 \\
\hline \begin{tabular}{c} 
Outplacement and redundancy \\
\hline
\end{tabular} & 0.375 & 0.485 & 1.357 & 1.814 & 1.857 & 2.129 & 3.2014 & 3.114 & 3.457 \\
\hline
\end{tabular}

Source: Author's calculations.

When examining development trends over a period of ten years, the survey pointed to an increase in the use of outsourcing services in all monitored human resource management functions. The most significant increase was recorded in the areas of compensation and benefits of employees and in the area of outplacement and redundancy. The authors also recorded a very positive trend in the area of recruitment and selection of employees. Similarly, positive trends are also in the area of employee information services. 


\subsection{Utilization of modern technologies in provision of selected human resource management functions}

In the context of the arrival of the Fourth Industrial Revolution and the enormous beginning of IT technologies applicable in all spheres of social life, there is a growing need for businesses to respond adequately to these trends.

As a part of the analysis of the use of modern technologies for the provision of human resource management functions by organizations, the authors were interested in the utilization rate of organizations using modern technologies in selected HRM functions throughout the research period (Table 9).

Table 9

Utilization rate of modern technologies in selected HRM functions

\begin{tabular}{|l|c|c|c|c|c|c|c|c|c|c|}
\hline \multirow{2}{*}{} & \multicolumn{6}{|c|}{ Utilization rate of modern technologies in selected HRM functions (\%) } \\
\cline { 2 - 13 } & $\mathbf{2 0 1 0}$ & $\mathbf{2 0 1 1}$ & $\mathbf{2 0 1 2}$ & $\mathbf{2 0 1 3}$ & $\mathbf{2 0 1 4}$ & $\mathbf{2 0 1 5}$ & $\mathbf{2 0 1 6}$ & $\mathbf{2 0 1 7}$ & $\mathbf{2 0 1 8}$ & $\mathbf{2 0 1 9}$ \\
\hline Recruitment and selection & 8.2 & 8.3 & 8.7 & 9.1 & 9.0 & 10.2 & 10.3 & 10.7 & 10.5 & 11.4 \\
\hline Education and development & 12.4 & 11.3 & 10.8 & 11.1 & 12.8 & 14.5 & 17.3 & 19.8 & 23.4 & 26.6 \\
\hline Evaluation & 4.3 & 4.7 & 5.1 & 5.0 & 5.2 & 5.3 & 5.7 & 5.5 & 6.4 & 6.3 \\
\hline Compensation & 16.3 & 18.8 & 22.4 & 27.6 & 26.3 & 36.2 & 44.1 & 50.6 & 53.6 & 55.2 \\
\hline
\end{tabular}

Source: Author's calculations.

Organizations use modern technologies mainly in the area of employee education and development (more than 26\%), with over half of respondents using modern technologies (IT software) in the area of employee remuneration (Table 10).

Table 10

Base change index - a rate for usage of modern technologies in the provision of HRM functions

\begin{tabular}{|l|c|c|c|c|c|c|c|c|c|}
\hline \multicolumn{6}{|c|}{ Base change index - a rate for usage of modern technologies in the provision of HRM functions } \\
\hline & bi11/10 & bi12/10 & bi13/10 & bi14/10 & bi15/10 & bi16/10 & bi17/10 & bi18/10 & bi19/10 \\
\hline Recruitment and selection & 1.012 & 1.060 & 1.109 & 1.097 & 1.244 & 1.256 & 1.305 & 1.280 & 1.390 \\
\hline Education and development & 0.911 & 0.871 & 0.895 & 1.032 & 1.169 & 1.395 & 1.597 & 1.887 & 2.145 \\
\hline Evaluation & 1.093 & 1.186 & 1.163 & 1.209 & 1.232 & 1.325 & 1.279 & 1.488 & 1.465 \\
\hline Compensation & 1.153 & 1.137 & 1.693 & 1.613 & 2.221 & 2.706 & 3.104 & 3.288 & 3.386 \\
\hline
\end{tabular}

Source: Author's research

The survey showed that Slovak organizations are currently making progress in the use of new technologies in each of the monitored functions. The greatest increase in the use of modern technologies was recorded, on the one hand, in the function of employee education and development, and on the other hand, even more significantly in the area of employee compensation.

\section{DISCUSSION AND CONCLUSION}

The growing interest in the quality of job potential formation, its continuous development, motivation in order to achieve a continuous orientation towards the organization and identification of employees with a formulated strategy emphasizes the importance of a systemic approach to human resource management. The strategic orientation and application of the system approach in human resource management is a way of responding to the tendencies that globalization creates in the form of international business cooperation 
on the one hand and severe hyper-competition on the other. This puts significant pressure on the human resource departments and therefore the survey conducted by us shows a positive finding of the growth of such departments over the last ten years. When comparing the data obtained with the worldwide study of the CRANET research network of more than 6,090 respondents, we have noted that Slovak organizations have taken this trend, although gradually, but are reaching the level of European countries where the human resource management department is established in organizations organizational structure in Italy $(100 \%)$, Spain $(99.0 \%)$, Germany $(98.5 \%)$, Switzerland $(99.5 \%)$, the least stable part of corporate structures is reported by Lithuania $(73.8 \%)$, Croatia $(75.4 \%)$, Cyprus $(77.0 \%)$ and Slovenia $(77.2 \%)$. This is important because the human resource department has a crucial impact on the formation of both personnel and organizational strategies. When creating the strategy of the organization, it is essential that the head of the human resource unit is involved, and thus that he is a part of the top management of the organization. The survey showed that only more than $50 \%$ of senior human resource managers hold such a position. A similar result was also seen in the analysis of the existence of documents defining personnel strategy in Slovak organizations. Compared to the Cranet survey, $67.1 \%$ of organizations in Finland and over $80 \%$ of organizations in Sweden form a personnel strategy in writing.

It is the partnerships created by long-term mutually beneficial cooperation that can significantly strengthen the capacity of the human resource management unit and be a source of its competitiveness. Slovak organizations use outsourcing mainly in the area of employee education and development, which is probably because many organizations, especially smaller ones, do not have enough qualified lecturers and training centers and therefore outsource this function. The authors noted a very positive trend especially in the area of recruitment and selection of employees. These trends can be attributed to the development of the labor market, wherein the period under review there was a significant decrease in the number of job seekers on the labor market. While unemployment in 2013 was at $14.26 \%$, by 2019 it had fallen to $4.88 \%$ (ÚPSVaR). There is a similarly positive trend in the area of information services for employees. The authors attribute this trend to technological progress and the related increase in the demands of the use of IT technologies as well as the increase in the quality of services provided in this area. While in 2010 service offerings in this area were almost exclusively pointed towards payroll software, the offer is now much more diverse and complex. Services are available, for example, on the preparation of labor-law documents, searching for and recruiting new employees, recording and securing OSH, statutory medical care, or employee education. Thanks to the new technologies, this data can be accessed via portal from virtually anywhere with maximum security.

Based on this article, a new space for research opens up for us, within which we will monitor the level and content of the changes that companies are actually introducing into their economic practice., We will monitor the attitude of companies and their readiness for the Industrial Revolution 4.0, which is still in its infancy, but the changes it brings, significantly change the job market, as well as the content of the required competencies from employees. The physical strength or specific physiological characteristics of employees are important only in narrow profile jobs. Knowledge, educational degree or sectoral qualifications face the demands of flexibility in today's labor market. Competence and time are becoming a commodity of the world of work in the era of industry 4.0. Changes in the world of work in industrial conditions 4.0 determine labor market conditions. In an era of an advanced digitization and knowledge society hyper-connectivity, competencies define the commodity content of the labor market of industry 4.0. Employee competence analysis is the basis for defining specialized strategies for job potential formation and employee performance management. 


\section{ACKNOWLEDGEMENT}

The research, whose results were processed in this paper was supported by the grant APVV-17-0656 entitled Transformation of Organizational Management Paradigm in the Context of Industry 4.0 and by the grant VEGA 1/0412/19 Systems of Human Resources Management in the 4.0 Industry Era.

\section{REFERENCES}

Armstrong, M. (1999). A Handbook of Human Resource Management Practice. London: Kogan Page.

Bajzíková, L., Fratričová J., \& Kirchmayer, Z. (2019). Základy personálneho maną̌mentu. Bratislava: University of Comenius.

Baykal E. (2020). Digitalization of Human Resources: e-HR, In: (Meral I., Ed.) Tools and Techniques for Implementing International E-Trading Tactics for Competitive Advantage, p. 1-19, DOI: 10.4018/978-1-7998-0035-4.ch013.

Bilan, Y., Mishchuk, H., Samoliuk, N., \& Grishnova, O. (2019). ICT and Economic Growth: Links and Possibilities of Engaging. Intellectual Economics, 13(1). DOI: https://doi.org/10.13165/IE-19-13-1-07

Blštáková, J., Joniaková, Z., Jankelová, N., Stachová, K., Stacho, Z. (2020). Reflection of Digitalization on Business Values: The Results of Examining Values of People Management in a Digital Age. Sustainability, 12, 5202.

Blyton, P., \& Turnbull, P., (Ed.). (1992). Reassessing Human Resource Management: Conflicts and Contradictions Publications. Thousand Oaks: SAGE.

Cagáňová, D., Stareček, A., Horňáková, N., \& Hlásniková, P. (2019). The Analysis of the Slovak Citizens’ Awareness about the Smart City Concept. Mobile Networks and Applications 24(6), 2050-2058

Chukwunonso, F. (2013). The development of human resource management from a historical perspective and its implications for the human resource manager, In: (Tiwari M., Tiwari I, Shah S., Eds) Strategic Human Resource Management at Tertiary Level, Rivers Publishers, pp. 87-101.

Ericksen, J., \& Dyer, L. (2005). Toward a Strategic Human Resource Management Model of High Reliability Organization Performance. International Journal of Human Resource Management. 16(6), 907-928.

Gorb, P. (1951). Robert Owen as a Businessman. Bulletin of the Business Historical Society, 25(3), 127-148. doi: $10.2307 / 3111280$

Green, M.E. (2002). Internal Human Resources Consulting: Why Doesn't Your Staff Get It? Public Personnel Management. 13(1), 111-132.

Guest, D.E. (1991). Personnel Management: the end of Prthodoxy. British Journal of Industrial Relations, 29(2), 149-176.

Hitka, M., Lorincová, S., Ližbetinová, L., Bartáková, G. P., \& Merková, M. (2017). Cluster Analysis Used as the Strategic Advantage of Human Resource Management in Small and Medium-sized Enterprises in the WoodProcessing Industry. BioResources, 7884-7897.

Jenco, M., Droppa, M., Lysa, L., Križo P. (2018). Assessing the Quality of Employees in Terms of their Resistance. Quality-Access to Success 19(167), 48-53.

Joniakova, Z., \& Blstakova, J. (2015). Age Management as Contemporary Challenge to Human Resources Management in Slovak Companies. 9th International Scientific Conference on Business Economics and Management (BEM), Tech Univ Zvolen, APR 30 - MAY 02, 2015 Book Series: Procedia Economics and Finance 34, p. 202-209

Kampf, R., Lorincová, S., Hitka, M., \& Stopka, O. (2017). Generational Differences in the Perception of Corporate Culture in European Transport Enterprises. Sustainability (9), 9, 1561, doi:10.3390/su9091561

Kepes, S., \& Delery J. E. (2007). HRM systems and the problem of internal fit. In: Boxall, P. et al. (Eds). The Oxford University Press Handbook of Human Resource Management. Oxford: Oxford University Press.

Koubek, J. (2007). Řizení lidských zdrojü, Management Press, p. 399.

Kucharcikova, A., \& Miciak, M., (2017). Human Capital Management in Transport Enterprise. 18th International Scientific Conference on LOGI, Ceske Budejovice, Czech Republic, Oct. 19, 2017. MATEC Web of Conferences, p. 134.

Mabey, C., Skinner, D., \& Clark, T., (Eds.). (1998). Experiencing buman resource management. London: Sage, p. 265.

Mach, J. (1932). Bat'a z blizka, Praha: Orbis, p. 95. 
Makarova I., Shubenkova K., \& Pashkevich A. (2018). Development of an Intelligent Human Resource Management System in the Era of Digitalization and Talentism, 18th International Conference on Mechatronics - Mechatronika (ME), Brno, Czech Republic, p. 1-6.

Papula, J., Kohnova, L., \& Papulova, Z. (2018). Impact of national culture on innovation activities of companies: A case of Germany, Austria, Switzerland and the Czech Republic. Economic annals-XXI, (169), 26-30.

Poór, J., Juhász, T., Machová, R., Bencsik, A., \& Bilan, S. (2018). Knowledge management in human resource management: Foreign-owned subsidiaries' practices in four CEE countries. Journal of International Studies, 11(3), 295-308. doi:10.14254/2071-8330.2018/11-3/23

Raišienè, A.G., Rapuano, V., Varkulevičiūtė, K., \& Stachová, K. (2020). Working from Home—Who Is Happy? A Survey of Lithuania's Employees during the COVID-19 Quarantine Period. Sustainability, 12, 5332.

Rapuano V. (2020). Toward Sustainable Careers: Literature Review, Contemporary Research on Organization Management and Administration, 8(1), 41-54.

Reidy, L. (2015). Human Resource Management. Dublin: Gill.

Skott, W., Clothier, R., Mathewson, S., \& Spriegel, W. (1941). Personnel Management Principles, Practices and Point of View. New York: McGraw-Hill.

Slovenské národné stredisko pre l’udské práva (2019). Právo a inštitúcie - OSN. Available on the web at: https://www.gender.gov.sk/diskriminacia/dokumenty/osn/

Sorko S. R., Rabel B., Richter H. M. (2016). The Future of Employment - Challenges in Human Resources through Digitalization, Industry 4.0,1(2), p. 128-131

Stacho, Z., \& Stachova, K. (2015). The Extent of Education of Employees in Organisations Operating in Slovakia. 12th International Conference on Efficiency and Responsibility in Education (ERiE), Prague, Czech Republic, Jun 04-05, pp. 548-555.

Stacho, Z., Stachová, K., Hudáková, M., \& Stasiak-Betlejewska, R. (2017). Employee adaptation as key activity in human resource management upon implementing and maintaining desired organisational culture. Serbian Journal of Management, 12(2). 303 - 313.

Stacho, Z., Stachová, K., Papula, J., Papulová, Z., \& Kohnová, L. (2019). Effective communication in organisations increases their competitiveness. Polish Journal of Management Studies, 19.

Tabatabaei, S. A. N., Omran, E. S., Hashemi, S., \& Sedaghat, M. (2017). Presenting Sustainable HRM Model Based on Balanced Scorecard in Knowledge-based ICT Companies (The Case of Iran), Economics and Sociology, 10 (2), $107-$ 124. DOI: $10.14254 / 2071-789 X .2017 / 10-2 / 8$

Vojtech, F., Levický, M., \& Filip, S. (2019). Economic policy for sustainable regional development: a case study of Slovak Republic, Journal of Security and Sustainability Issues, 8(4): 597-608. http://doi.org/10.9770/jssi.2019.8.4(4)

Vojtovič, S. (2006). Personálny manažment, Bratislava: Iris. ISBN 80-89018-98-X

Zhou, Y., Liu, G., Chang, X., \& Wang, L. (2020). The impact of HRM digitalization on firm performance: investigating three-way interactions. Asia Pacific Journal of Human Resources. doi:10.1111/1744-7941.12258 